Relations industrielles

Industrial Relations

\title{
Decentralization of Bargaining Structure
}

Four Cases from the U.S. Paper Industry

Décentralisation des structures de négociation

Quatre cas tirés de l'industrie du papier américaine

\section{La descentralización de la estructura de negociación}

Cuatro casos de la industria del papel en los Estados Unidos

\section{Adrienne E. Eaton et Jill Kriesky}

Volume 53, numéro 3, été 1998

URI : https://id.erudit.org/iderudit/005275ar

DOI : https://doi.org/10.7202/005275ar

Aller au sommaire du numéro

Éditeur(s)

Département des relations industrielles de l'Université Laval

ISSN

0034-379X (imprimé)

1703-8138 (numérique)

Découvrir la revue

Citer cet article

Eaton, A. E. \& Kriesky, J. (1998). Decentralization of Bargaining Structure: Four Cases from the U.S. Paper Industry. Relations industrielles / Industrial Relations, 53(3), 486-516. https://doi.org/10.7202/005275ar

Tous droits réservés (C) Département des relations industrielles de l'Université Laval, 1998
Ce document est protégé par la loi sur le droit d'auteur. L'utilisation des services d’Érudit (y compris la reproduction) est assujettie à sa politique d'utilisation que vous pouvez consulter en ligne.

https://apropos.erudit.org/fr/usagers/politique-dutilisation/ 


\title{
Decentralization of Bargaining Structure
}

\section{Four Cases from the U.S. Paper Industry ${ }^{1}$}

\author{
ADRIENNE E. EATON \\ Department of Labor Studies and Employment Relations, Rutgers University. \\ JILL KRIESKY \\ Institute for Labor Studies and Research, West Virginia University.
}

\begin{abstract}
In recent years, there has been a trend in many countries toward a decentralization of collective bargaining structures. This study employs two methods to provide a deeper analysis than previous studies of the forces that determine bargaining structure. First, it builds a framework to analyze bargaining structure by integrating previous theoretical and empirical work on the topic. Second, it applies the framework to four bargaining unit level case studies in the United States' pulp and paper industry. By examining the dissolution of two centralized bargaining structures and union attempts to reestablish centralization through ratification voting pools in two others, the study reveals the relative importance of economic, tactical and organizational factors in the continued decentralization of U.S. paper industry bargaining.
\end{abstract}

For some time, industrial relations scholars have recognized that an important component in the "crisis" in American labour relations has been the decentralization of bargaining structures (for an early example, see Kochan and Piore 1983). Indeed, there is ample evidence that bargaining structures are becoming more decentralized in countries around the globe (Katz 1993). In the U.S., at least, this decentralization has been associated with declining union bargaining power and deteriorating outcomes for unions and their members (Kochan, Katz and

1. We would like to thank the various union and management officials who were interviewed for this paper. 
McKersie 1986; Katz 1993; Voos 1994). Even more drastically, decentralization of both formal and informal bargaining structures hinders the efforts of unions in the U.S. to take labour costs out of competition, a central goal of virtually all trade unions in developed market economies.

The U.S. paper industry represents a case in point. ${ }^{2}$ Although bargaining structures in the industry historically were relatively decentralized, these structures have experienced a long-term trend toward further decentralization over the last thirty years. While precise data are unavailable, estimates at two different points in time point to the mixed nature of structures in the industry. In 1955, Macdonald (1956: 106) estimated that 20-25 percent of the industry was covered by multi-company, company-wide or multi-mill agreements. In 1975, Lipsky (in Kochan 1980) reported that 50 percent of paper industry agreements covered a single mill. While a few multi-facility structures remain, the two most important met their demise in the 1980s. A significant deterioration in the bargained terms and conditions of employment in the industry soon followed (for details see Eaton and Kriesky 1994). ${ }^{3}$

While the fact of decentralization is widely acknowledged, the reasons for it and the processes by which it has occurred have received relatively little attention. Perhaps the most ambitious effort is Katz' study of decentralization in six countries (1993). Katz offers three hypotheses to explain the trend: a shift in management bargaining power, diversification in corporate structures and worker interests, and widespread work reorganization. While he finds evidence to support all three hypotheses, it is the latter explanation that he finds most "influential". Voos also generates explanations for decentralization based on a review of twelve industries in the U.S. She argues that "employers have been the driving force behind the move to decentralize" (1994: 7). Their goals, in her view, are increased bargaining leverage and increased competitive

2. The Canadian paper industry historically was more centralized. It was characterized by two large, regional multi-firm structures, one in the East and one in the West. These structures came under pressure and were weakened or abandoned in the early 1990s at the employers' initiative. As with other changes in the Canadian paper industry, this development lagged similar developments in the U.S. by a few years.

3. The degree of pattern bargaining is harder to determine. Industry observers agree that prior to the 1980s there were fairly definite regional patterns (Greenberg 1966) with the Uniform Labor Agreement and Southern Kraft Multiple as leaders. These two agreements may also have been pattern setters for some agreements in other regions. The end of the ULA and SKM left the industry with no clear leaders in the 1980s and a number of divergent labour relations patterns emerged (Walton et al. 1994; Eaton and Kriesky 1994). 
advantage through reduced labour costs and more productive work systems.

The case study method used by both Katz and Voos constitutes a return to the approach used by scholars attempting to understand the evolving post-war bargaining system in its formative days. Weber's 1961 volume, for instance, includes detailed case studies of bargaining structure in meat packing, steel, chemicals, airlines, construction and farm machinery. Based in part on this work, Weber (1967), hypothesized five categories of bargaining structure determinants: scope of product and labour markets, focal issues of negotiations, internal organizational issues, government policy, and tactical and power considerations of the parties.

Hendricks and Kahn (1982) advanced the theoretical understanding of bargaining structures by arguing that they reflect labour and management preferences and, when these preferences collide, the relative power of one of the parties to impose its preference on the other. Like other scholars studying bargaining structure after Weber (Greenberg 1966; Deaton and Beaumont 1980), Hendricks and Kahn used a quantitative empirical approach and focused largely on product and labour market characteristics. In two separate analyses they regress the probability that an agreement is (1) multi-employer and (2) single-employer but firm-wide (a more restrictive condition than simply multi-facility) on several economic variables. Unfortunately, these analyses did not directly test their theoretical model. Rather, they identified certain relationships without explaining them. In addition, as the authors themselves admit, because the analysis is cross-sectional it is ill-equipped to deal with changes in structure.

Since Hendricks and Kahn drew attention to the parties' preferences for certain structures, industrial relations scholars have increasingly recognized the contribution of "strategic choices" by the parties to a range of outcomes (Kochan, Katz and McKersie 1986). Choice is also useful in understanding bargaining structures, particularly changes therein. We believe that changes in bargaining structures, including recent decentralization, reflect alterations in one or both parties' preferences and, where the parties' preferences have clashed, an alteration in the balance of power.

This paper centres on four case studies of bargaining structures within the U.S. paper industry. Two of the cases involve the dismantling of the most important pattern-setting structures in the industry. They were selected because of their importance to bargaining in the industry overall. Indeed, their dismantlement was directly followed by an erosion 
of contract terms throughout the industry. The other two cases involve attempts by the major union in the industry to reestablish a degree of centralization through the creation of ratification voting pools. ${ }^{4}$ The voting pool strategy was significant because it was the major mechanism chosen by the union to resist the concessionary trend. In the voting pool cases, the union was the clear instigator of attempted change and they therefore provide a counterpoint to the dismantlement cases. In one dismantlement case, management was the instigator while in the other that role was more shared. Finally, this focus on an industry, combined with the use of case studies, provides a deeper and richer analysis of the forces that determine bargaining structure than previous studies.

\section{MANAGEMENT PREFERENCE IN BARGAINING STRUCTURES}

In the following sections, the various factors explaining bargaining structure preferences are grouped into three categories - market (or economic), tactical and organizational factors. We first examine possible explanations for an alteration in management preferences for particular bargaining structures and then turn to labour's preferences. It should be noted that the cases include two examples in which labour had a clear preference for centralization, one in which management showed a clear preference for decentralization and one in which the preferences are more difficult to discern. Table 1 provides a guide to the discussion.

\section{Economic or Market Factors}

Despite the longstanding observation that product and labour market factors are associated with certain types of bargaining structures (e.g., Weber 1961), the literature is rather tentative about the contribution of economic factors to management's preference for a particular structure. Kochan and Katz (1992) argue that small unionized firms operating in highly competitive, often local, markets can stabilize competition through multi-firm structures. Several studies have shown that multi-firm structures are indeed found in manufacturing industries with lower concentration ratios and high labour intensity (Greenberg 1966; Deaton and Beaumont 1980; Hendricks and Kahn 1982). However, the paper industry multi-

4. Ratification voting pools were used in bargaining by the United Paperworkers International Union (UPIU) with several companies in the mid- to late 1980s. The pools represented a union attempt to establish a degree of de facto bargaining centralization through pooling ratification votes from various locals of a particular company. Each local would send its ratification vote to the international union for counting. None of the participating locals were to sign an agreement if a majority of the pool voted for rejection. 
TABLE 1

Summary of Hypotheses Regarding Management and Union Preferences for Centralized or Decentralized Bargaining Structure

I. Factors Increasing Management's Preference for Decentralized Bargaining Structure Economic/market factors

Broadening of product markets or integration of regional operations into a national or international production strategy (Hendricks and Kahn)

Diversification of product lines (Hendricks and Kahn)

Increased competition resulting from declining market concentration, deunionization, or foreign competition (Voos, Katz)

Tactical factor

Belief that decentralization would increase management's bargaining power (Hendricks and Kahn, Katz)

Organizational factors

Decentralization of decision making in corporate structure (Katz, Cushman) Management pursuit of work reorganization (Katz)

II. Factors Influencing Union's Preference for Bargaining Structure

A. Factors Encouraging Centralization

Economic/market factors

Use of formal or informal centralization to take wages out of competition

(Fiorito, Gramm and Hendricks)

Tactical factors

Belief that centralization would increase union bargaining power

Organizational factors

Centralization can be efficient method for achieving bargaining goals (Fiorito et al.)

B. Factors Encouraging Decentralization

Tactical factors

Belief that decentralization would not decrease bargaining power

Organizational factors

Local unions prefer autonomy allowed by decentralization (Fiorito et al.)

Rising importance of local work reorganization as bargaining issue (Weber, Fiorito et al., Katz)

III. When Union and Management Preferences Clash

Relative power of parties will determine outcome (Hendricks and Kahn, Voos, Katz)

employer structure examined below does not fit this model. Hendricks and Kahn also found that local and regional (versus national) markets are associated with multi-employer structures in manufacturing (see also Deaton 
and Beaumont 1980). They argue that this reflects increasing costs to one or both parties as markets broaden. This suggests a hypothesis: the collapse of the multi-employer structure in the paper industry could have been motivated by the broadening of the market or the integration of at least some of the companies' regional operations into their national or international production strategy.

The dynamics surrounding single-employer, multi-facility structures are different. Hendricks and Kahn argue that there may be economies of scale for multi-facility employers (and unions) to centralize bargaining within the firm, particularly when most facilities are organized by a single union (Hendricks and Kahn). Over three decades ago, Livernash (in Weber 1961) observed that diversification in product lines could prompt companies to dismantle corporate-wide bargaining structures and replace them with local bargaining. ${ }^{5}$ Thus, a second explanation for the collapse of the centralized structures and management resistance to them could be increased diversity in product lines.

Beyond that, the existing literature has little to say about the economic factors influencing employers' preferences. This is because the other factors discussed below have been more powerful and because union preferences have historically been more determinative. This does not mean, however, that economic factors play no role in changes in bargaining structure. Voos (1994) argues that the decline in union coverage of product markets in the last two decades has motivated management to seek decentralized structures. Management had an interest in centralized structures when product markets were highly unionized and labour costs were taken out of competition. As competition increased and "absolute" power

5. Indeed, management representatives from the paper industry argue that the dominance of decentralized bargaining in the industry historically resulted in large part from product diversity (Klinzing interview) The market, social, and political factors contributing to this initial decentralization are beyond the scope of this paper. A number of explanations beyond product diversity can be offered, some of which are mentioned in the text. One factor is the social character of paper production. Historically, mills were located in isolated rural areas in the four principal regions of U.S. paper production. Except in the West, this isolation did not foster centralizing impulses on either side of the table. In fact, the significant centralized structures in the industry appear within particular regions of the country. This is consistent with Hendricks and Kahn's observation that wide geographical dispersion of facilities increases the costs of centralized structures to a prohibitive level. In addition, other continuous process industries developed fewer centralized structures than other industries similarly characterized by large, multinational firms and high levels of union organization (Kochan 1980: 95; see also Livernash in Weber 1961: 46). In these cases, traditional Marshallian factors like difficult substitutability due to high skill levels and low labour intensity, may have provided sufficient bargaining power to unions outside of centralized structures 
(Katz 1993: 13-14), that is, the power "held by both management and unions" to extract economic rents, decreased, management pursued more flexible structures. This suggests a third hypothesis, that increased competition in the paper industry prompted companies to oppose centralization.

\section{Tactical Factors}

Several observers have pointed out that the particular structure that will yield management tactical advantage is theoretically ambiguous (Hendricks and Kahn 1982; Katz 1993). It might be more accurate to say that it is situationally contingent. That is, certain structures offer more power to management under certain economic circumstances. For instance, when the environment allows a union to wield power through effective local work stoppages, centralization can eliminate the union's whipsaw.

At the same time, it may not always be possible to predict what structure will be most effective. For instance, employers in the San Francisco hotel industry made a strategic error when they pulled out of a multiemployer association in the 1980s (Cobble and Merrill 1994: 470). Successful union whipsawing quickly caused many to "reconsider their decision." However, we do not conclude, as Katz (1993: 16) seems to, that because the power implications of bargaining structure are shifting that they do not play an important, indeed essential role in determining the parties' structural preferences. We hypothesize that management sought to dismantle centralized structures and resisted union efforts at centralization because they thought decentralized structures would offer them greater relative power.

\section{Organizational Factors}

Decentralized bargaining structures offer local management more autonomy over decision making. However, since companies are not operated democratically, the desire from the ranks for autonomy has not tended to influence management's choice of structure. On the contrary, bureaucracy's need for centralized control and coordination of labour relations policy creates more imperatives in that direction (for a debate on this topic, see Weber 1961: 97-105). However, in recent years, management has moved to decentralize corporate structures and decision making. Some companies have sought to increase their flexibility and responsiveness to market pressures by creating independent profit centres with significant decisionmaking autonomy. Decentralization in bargaining could simply reflect a new corporate structure (Katz 1993; Cushman in Weber 1961: 64). Further, local management has operated more independently especially regarding issues of work reorganization aimed at promoting efficiency. Thus, we 
hypothesize that corporate decentralization in the paper industry motivated management to prefer decentralized bargaining structures.

\section{UNION PREFERENCE IN BARGAINING STRUCTURES}

\section{Economic or Market Factors}

Labour's fundamental economic interest in bargaining structure is to take labour costs out of competition by organizing and setting standards for an entire product market (Weber 1967). In the post-war U.S., unions have achieved this goal through collective bargaining and have thus sought to match bargaining structures to product market structures, either through formal multi-employer structures or informally through pattern bargaining. Successful pattern bargaining, from a union perspective, requires the ability to whipsaw individual companies or facilities into the pattern. Fiorito, Gramm and Hendricks (1991: 120) refer to this union approach as the "monopoly strategy" and argue that a union's "incentive to centralize should be strongest where [anti-union] whipsawing possibilities are greatest and/or product market competition most intense".

This basic motivation for centralization is unlikely to have disappeared in the 1980s. However, historically, the paper unions in the U.S. relied largely on pattern-setting to standardize wages within regions and, to a lesser degree, nationally (Eaton and Kriesky 1994; Walton et al. 1994). Thus, any changes in formal bargaining structure sought or agreed to by the paper unions must take into account the utility of pattern-setting at the time of the change. Specifically, we can hypothesize that if the paper unions sought or agreed to dismantle centralized structures they did so believing they would continue to take wages out of competition through pattern-setting. Relatedly, attempts to create new formally centralized structures would have been motivated by the failure of pattern-setting through informal mechanisms. Finally, as an alternative to either formal or informal centralization, the unions could have abandoned attempts to take wages out of competition, following instead what Fiorito, Gramm and Hendricks refer to as an "efficiency strategy". This strategy maintains wages by ensuring firm success through union participation in management. We say more about the implications of the efficiency strategy below in the section on organizational factors.

Fiorito, Gramm and Hendricks (1991: 121) suggest an additional factor which they label the "wage myopia problem", the possibility that individual local unions will bargain for a wage too high or too low to maximize welfare for all unions in a particular market. Where the national union recognizes the existence of this problem, either because locals misjudge management's response or lack information, it will attempt to centralize bargaining. This sug- 
gests a motivation for the attempts to centralize bargaining through pooling of contract votes: locals reaching agreements detrimental to the "greater good" of the membership as a whole.

\section{Tactical Factors}

Like employers, unions will prefer bargaining structures that enable them to increase their power and avoid the negative whipsaw. This depends, as it does for management, on the sources of bargaining power in any given context. While a democratic structure and ethos exert a more or less constant decentralizing pressure, that pressure is often overcome by tactical and economic considerations. The importance of tactical concerns suggests another pair of hypotheses: (1) the paper unions believed that decentralization would either increase or maintain their power and (2) attempts to recentralize through pools were motivated by a desire to increase bargaining power.

\section{Organizational/Political Factors}

As suggested above, organizational factors are particularly salient in determining union preferences for particular bargaining structures. Decentralization affords local unions more autonomy (Weber 1961; Hendricks and Kahn 1982; Fiorito, Gramm and Hendricks 1991). While the economic context may encourage some form of centralization, the democratic nature of unions mitigate against it. Fiorito, Gramm and Hendricks (1991: 118) argue, for instance, that U.S. unions prefer decentralization unless it proves to be "a highly inefficient method of achieving goals."

In this regard, it is important to note that the two unions in the paper industry have a history rooted in strong local control and democracy. The independent Association of Western Pulp and Paper Workers (AWPPW) broke away from the larger paper craft unions in the early 1960s over the issue of centralized control of bargaining by the nationals. The United Paperworkers International Union (UPIU) is a very late (1972) amalgamation of former craft unions which remain unmerged at the local level. We hypothesize that the dismantling of the centralized structures as well as the failure to create new centralization through voting pools is in part a function of the particular balance of power between the national and local unions.

Beyond these axioms, Weber (1961) and Fiorito et al. (1991) suggest additional organizational factors which make unions less inclined to centralize bargaining. In particular, Weber argued that some bargaining issues have "market-wide" implications, while others are "essentially local in nature" and that structure would "reflect the substantive emphasis of negotiations at any point in time in a specific relationship" (1967: 17). Katz (1993) concludes that the rise of work reorganization, an "essentially local" issue in his view, to the 
top of both parties' bargaining agendas was the most significant determinant of decentralization during the 1980s. Fiorito et al. (1991: 122-123) similarly argue that unions pursuing the "efficiency strategy" will "decentralize control over bargaining". This is because efforts to improve performance, in their view, require changes to work rules and the development of worker participation programs, both of which are essentially local issues. Thus, work reorganization may have provided a motive for labour, or indeed for both parties, to pursue more decentralized bargaining in the cases described below.

It is important to note that this hypothesis assumes that "efficiency strategies" are essentially local in nature. However, many U.S. unions have shown a clear preference for partnerships at a more strategic, hence national level (Schurman and Eaton 1996). Further, Kochan and Katz point out that "unions will benefit if the structure of bargaining is coterminous with the level at which critical management decisions are being made" (Kochan and Katz 1992: 188). Thus, an "efficiency strategy" that emphasizes union involvement at the strategic level might encourage or enhance centralized bargaining. ${ }^{6}$ Our examination of "efficiency strategies" in the paper industry will explore these alternative possibilities.

\section{WHEN PREFERENCES CLASH: BARGAINING POWER}

As noted above, Hendricks and Kahn (1982) observe that when labour and management's preferences for bargaining structure clash, one parties' greater relative power will determine the outcome. ${ }^{7}$ Public policy, as expressed in labour law, is of particular importance in resolving disputes over bargaining structure. Prior to the 1980s, most observers felt that National Labor Relations Board decisions tended to encourage centralization of bargaining structures (Kochan 1980: 100; Weber 1967). This view, however, fails to recognize an important distinction between legally recognized election units and essentially voluntary bargaining units (Dunlop in Weber 1961: 2531). The large centralized structures with which the U.S. industrial relations community is familiar, like the multi-plant agreements between the major

6. For instance, AT\&T's unions have exercised consistent pressure through their joint unionmanagement program, Workplace of the Future, to maintain centralized bargaining despite AT\&T's devolution first into semi-autonomous business units and then into three separate companies. As of the time of writing, it appears that centralized bargaining will continue within though not across the new telecommunications equipment and services companies.

7. Most readers will be familiar with traditional measures of union bargaining power which focus on the union's ability to impose costs on management, typically by reducing or stopping production. Less often recognized sources of union strength relate to the union's ability to muster support from various other stakeholders to the firm, including suppliers, customers, other workers, investors, and policy makers or what might be termed the union's social resources. 
automakers and the UAW, are, in fact, voluntary arrangements. If one side objects, as employers increasingly did during the 1980s, the law recognizes the election unit as the relevant unit for negotiations.

Both Voos (1994) and Katz (1993) offer the increase in management's relative power in the 1980s as a prominent explanation for decentralization. Thus, we can hypothesize that when the parties' structural preferences clashed in the paper industry, the preference of the party with the greater relative power prevailed.

\section{THE CASE STUDIES}

The following sections evaluate the hypotheses listed above by tracing the evolution of the bargaining structure in four different locations within the pulp and paper industry. These cases provide a window into the "black box" of bargaining structure determination and allow us to better identify the complex set of forces driving change in that structure. Focusing on the level of the bargaining unit allows us to evaluate more directly the parties' actual preferences.

The first case concerns the final dismantling of the multi-employer structure in the Northwest. The task in this case is both to identify the parties' preferences and to explain them. The second case examines the dissolution of the other most important centralized structure, International Paper's multi-mill regional structure known as the Southern Kraft Multiple (SKM). Here it is clear that management initiated the change and so the task is to explain that initiation as well as to describe and explain labour's reaction to it. The last two cases deal with unsuccessful union attempts to reestablish a degree of centralization through ratification voting pools. While the pool strategy was used in other companies, these two are the best documented and involved the largest number of locals, and, in the case of IP, the largest company in the industry. ${ }^{8}$ These cases are also particularly useful in examining what happens when bargaining structure preferences clash.

8. In 1986, UPIU, facing declining first-year wage increases and new demands for concessions such as the elimination of premium pay for weekend work and the development of team production through changes in job classification structures and related work rules (often referred to as "crewing"), developed a new strategy to fight back. Specifically, the union attempted to establish a degree of de facto bargaining centralization through pooling ratification votes from various locals of a particular company. At its 1988 convention, UPIU actually amended its constitution (Article XV, Section 4) "to provide pooled voting procedures" (The Paperworker, August/September 1988: 14). In addition to Champion International and IP, both discussed at length in the text, between 1986 and 1990 pools were used in bargaining with Stone Container, Great Northern Nekoosa, Inland Container, Boise Cascade, Jefferson Smurfit and GeorgiaPacific (Beck 1988: 5; Pulp and Paper, 9/89: 246 and 1/90: 78; Johnston interview). 
The case studies draw on numerous source materials, including both secondary and primary sources. The former include both published and unpublished documents including union newspapers and bargaining reports, industry publications, collective bargaining agreements and legal decisions. In addition, interviews were conducted with seven union representatives from the two major paper unions and nine management representatives from five companies and two employer associations.

\section{The Pulp and Paper Employers' Bargaining Council}

In 1981, twenty-three locals of the Association of Western Pulp and Paper Workers (AWPPW) and seven companies came together in the only multifirm bargaining structure in the U.S. industry at that time. ${ }^{9}$ This structure sought to recreate an earlier pattern-setting structure in the Northwest known as the Uniform Labor Agreement (ULA). The ULA emerged out of a mutual agreement of the two major AFL paper unions and most of the west coast employers shortly after a wave of successful organizing in the 1930s (Guthrie 1972; Graham 1970). At its high point, the ULA covered approximately 20,000 workers producing a variety of products in forty-four mills owned by nineteen companies (Brotslaw 1964; Kerr and Randall 1948: 5) and set the pattern in the west coast paper industry.

Discontent with centralized bargaining first engendered the split from the AFL paper unions in 1964 and, soon afterward, the locals' push to break up or reform the ULA. ${ }^{10}$ However, when in 1967 the union proposed a bifur-

9. A similar centralized bargaining arrangement in western Canada, between two unions the Communication, Energy and Paperworkers Union and the Pulp, Paper, and Woodworkers of Canada and the Pulp and Paper Industrial Relations Bureau came under pressure and met its demise in 1994. At that time, the management organization refused to bargain centrally, and the British Columbia Labour Relations Board determined that bargaining structure was not a strike or lock out issue. After a six-week strike, a settlement was reached between the union and one employer which then set the pattern for agreements throughout western Canada (Bourque and Rioux 1997).

10. The split itself resulted primarily from local union displeasure with the conduct and results of centralized bargaining (Graham 1970: 121-132). Despite the formation of a new organization, discontent with centralization continued. Some locals of AWPPW actually attempted (unsuccessfully) to separate themselves from joint bargaining under the ULA (Guthrie 1972: 224). The differences surfaced from the moment the west coast locals were organized (Zieger 1984: 140, 181). In 1959, a struggle emerged within the two paper unions regarding bargaining strategy in the West. Interestingly, most of the large paper companies had company-wide pension and other "health and welfare" plans before unionization. With the advent of union representation, the companies refused to bargain over pensions apparently because they wanted to maintain company-wide plans but not engage in company-wide bargaining. This created a particular problem in the West, where the multi-employer association continually refused to bargain jointly over pensions but local mill bargaining on this topic was also ineffective (Brotslaw 1964: 215-216). In the late 1950s and early 1960s, local "insurgents" finally forced the national union leadership to take action against the companies in the form of an unfair labour practice charge (Levinson 1966: 125). 
cated structure allowing for some centralization as well local bargaining, the employers seized the initiative and began withdrawing from the centralized structure. By 1969 the ULA was gone; it was replaced by a variety of structures including single-employer, multi-mill bargaining (e.g., Boise-Cascade, Weyerhauser) and single-mill bargaining (Thompson interview).

Throughout the early 1970s, AWPPW locals engaged in "leapfrogging", taking advantage of different contract expiration dates to impose ever higher contract terms (The Rebel, March 29, 1985: 2). In 1975, the employers stopped this process by negotiating one-year contracts. The union, in turn, responded with a plan of its own aimed to re-establish pattern-setting. The plan called for local union strike votes in advance of bargaining; union-wide agreement on "economic guidelines"; a bargaining schedule (with various mills meeting in separate "rounds") determined by the union; and review of any potential pattern-setting agreement prior to ratification (The Rebel, February 10, 1978: 1, 4). Management refusal to follow the agreement the union designated as pattern-setting led to dozens of work stoppages. After two months of virtually no movement in bargaining, the AWPPW released locals from any centralized control and by May 1979, all agreements were signed (The Rebel, October 27, 1978: 1). The disruption resulting from the 1978 bargaining round pushed both parties into a multi-firm structure for the 1981 round.

The ground rules for 1981 provided that each mill would negotiate its local issues by a specified deadline or be dropped from the multi-employer "table." Ultimately, twenty locals and six companies bargained jointly, and only over monetary issues. The employers formed a new organization known as the Pulp and Paper Employers Bargaining Council (PPEBC). Delegates from each of the locals and the AWPPW president represented the union at the bargaining table. Despite a unanimous recommendation to reject, union members voted to accept the contract by a wide margin (The Rebel, April 10 and 24, 1981). This contract, which provided for minor improvements in wages, vacation time, shift differentials and health and welfare coverage, then set a pattern closely followed throughout the Northwest.

Although multi-employer bargaining was not completely satisfactory to either side, some players returned to it in 1983. Ten mills owned by three companies (Boise Cascade, Georgia-Pacific and Weyerhauser) participated in these negotiations (Pulp and Paper, May 1984: 29). Ultimately in this round, the PPEBC unilaterally implemented a final offer with substantially smaller wage increases than the union was accustomed to as well as some cost shifting in health care, and the elimination of mandatory shutdowns on three holidays (The Rebel, April 27, 1984). This agreement again set the pattern for the region (The Rebel, July 27, 1984). In 1987, the PPEBC dis- 
persed and the parties returned to company-within-region or mill-by-mill bargaining.

\section{Case Analysis}

When the moves and countermoves following the break-up of the ULA in the 1960s culminated in region-wide work stoppages, both labour and management went back to a formal centralized structure. Union leaders had pursued centralization expecting increased stability, labour peace and good contracts, essentially a return to life under the ULA. When, for various reasons, none of these outcomes resulted, the fiercely independent AWPPW locals concluded that they could negotiate better (or at least equal) contracts on their own.

Management's motives for abandoning multi-employer bargaining reveal a similar dynamic. As on the union side, an inherent conflict exists in multi-employer bargaining between the tactical need for unity and the need for individually tailored outcomes. The very success of employers in the early to mid-1980s, whether by centralized bargaining in the Northwest or decentralized bargaining elsewhere, sent a signal that unity was no longer required, the era of the whipsaw was over. Issues and approaches of particular importance to individual companies or mills that had been withdrawn in the intraorganizational bargaining process demanded attention. The individual interests of companies now outweighed the common interest (Gwartney and Reynolds interviews). Boise Cascade, for instance, pursued a cost shifting approach to retiree health care once freed from the constraints of the multi-employer unit, while others focused on different approaches or different issues (Gwartney interview). Other companies were affected by changes in both the human and corporate "players". Fiberboard, Publishers Paper and Crown Zellerbach, for instance, were sold to companies not formerly involved in the multi-employer structure. The founding members of the ULA, on both sides of the table, had retired or died and the new managers did not share the commitment to interfirm cooperation that had made the ULA possible.

Competition from the growing Southern paper industry also pushed work reorganization to the top of some companies' bargaining agendas. Indeed, two of the companies that did not participate in the 1984 multiple negotiations, ITT Rayonier and CZ, failed to complete local negotiations by the deadline due to unresolved issues on work organization and job flexibility (The Rebel, June 29, 1984; October 1, 1984; Lawton interview). Although neither company was ultimately successful in fully securing this language, they were willing to risk bargaining individually on the wage and benefit issues in order to get the work rule revisions they deemed necessary. Boise Cascade also pursued decentralized bargaining in the context 
of increased "flexibility". Thus, work reorganization was a motivating force, but not from the union side. Indeed, AWPPW was initially opposed to work reorganization and employee involvement.

Thus, the push for decentralization in this case did not originate from a permanent shift in the environment, like the broadening of regional markets or integration of regional operations with national ones. In fact, Southern producers, benefitting from earlier work reorganization as well as other cost advantages, were pushing into the Northwest's markets, not vice versa. Interestingly, the unified bargaining of the early to mid-1980s was the first attempt to deal with the deterioration in the Northwest's regional cost structures. Later, companies pursued concessions on their own.

\section{The Southern Kraft Multiple (SKM)}

Another major organizing success for the AFL paper Brotherhoods in the 1930s created a second centralized bargaining structure. In 1939, the Southern Kraft Corporation, a subsidiary of International Paper (IP), signed a labour agreement covering its eight southern mills (U.S. DoL 1967). Initially the mills included in the agreement were homogeneous with respect to the products made, thus earning the label the Southern Kraft Multiple (SKM). Over time they diversified into the production of various basic paper products. At times during its forty-five year history, the SKM represented as many as 15,000 workers at 10 mills (U.S. DoL 1967: 2). The SKM served as the pattern setter in the South. Many agreements in the North and Midwest also parallelled the SKM and even the notoriously independent Northwest began looking to the SKM in the 1950s (Levinson 1966).

The events leading to the breakup of the SKM began in 1981. In that year, IP told UPIU that is was not willing or able to make needed substantial capital investment in its Georgetown, SC mill unless the union agreed to contract language concessions allowing for greater flexibility in production work and, in the process, let that mill drop out of the multiple. UPIU agreed both to allow the mill out of the multiple and to give the concessions. By the 1983 negotiations, only six mills remained in the multiple. In 1984, IP argued that a single agreement for the entire multiple would make the mills uncompetitive given "growing product market problems" and the "diversity in size, vintage of capital stock, products produced and performance of these mills" (Birecree 1991a: 12).

UPIU agreed to the break-up without a struggle, judging that this was the only way to guarantee a future for any of the individual mills (Pulp and Paper, 1985: 140). Union President Glenn argued, "We got something in return for breaking up the bargaining block. We got a guarantee that IP would run the Camden, Arkansas, mill [Glenn's home mill] for two more 
years... IP agreed to modernize the other mills rather than close them down. It was a trade-off" (Pulp and Paper, May 1983).

Work reorganization was closely linked to the dismantling of the SKM and, as such, it is important to describe that linkage in some detail. The agreement negotiated at Georgetown after it left the SKM resulted in the implementation of reduced job classifications and multi-skilling. Yet, in the following year, the remaining six mills jointly negotiated language that was quite similar to that in the Georgetown contract (A Report to Our Employees 1983). This multi-facility contract provided local labour-management determination of lines of progression and training schedules thus permitting adjustments based on particular workplace technology and organization. However, it also contained language that limited management's prerogative to fill temporary vacancies, rotate assignments within a classification, reduce wages and schedule training (A Report to Our Employees 1983: 35-38).

\section{Case Analysis}

Management was the prime mover behind the dissolution of the SKM. Publicly, IP identified work reorganization as the reason for the change. However, with the exception of the Georgetown mill, reorganization occurred under a centrally bargained agreement (albeit with provision for local adjustments) prior to the break-up (Birecree 1991b). IP clearly had other motivations aside from work reorganization.

These motives were economic and, ultimately tactical although they had little to do with the traditional explanations regarding increased product diversity (product diversification had occurred many years before), deunionization or foreign competition. At the time of the SKM break-up, IP was in the midst of a severe financial crisis. IP had undertaken a substantial capital investment program in the late 1970s and early 1980s. However, at about the time the new equipment came on line, the industry as a whole hit a recession. IP could not recoup its investment, at least in the short run. Moreover, the investment community raised increasing criticism of the industry's performance and labelled it an unattractive investment (Konzelmann Smith, Birecree and Wilkinson 1996: 24). These financial problems, coupled with a sense that product markets were becoming more competitive, pushed IP to seek concessions from its unions and concessions were more easily obtained from individual mills (Gilliland interview). For its part, the union felt it had little real choice but to go along.

In this case, it becomes difficult to separate the issues of work organization and bargaining power. While Katz' contention that work reorganization may best be accomplished at the shop-floor level with input from those workers directly involved is, in general, correct (for a paper industry 
example, see Kriesky and Brown 1993), it does not require local bargaining, as he suggests. In the case of the SKM, the local that bargained on its own obtained less protective language. Decentralized bargaining made it more difficult for paper unions to resist work reorganization or to shape it. Indeed, IP (and other companies) proposed uniform language changes to locals throughout the corporation while simultaneously arguing that bargaining needed to become or remain separate (Birecree 1991b. ${ }^{11}$ This same pattern emerges in the pooling cases discussed below.

\section{Champion International (Champion)}

Champion manufactures a broad array of products from pulp and basic paper to a variety of consumer products and is among the top producers in the U.S. (Eaton and Kriesky 1994: 3). Champion's "white knight" takeover of St. Regis resulted in the ownership of several facilities with nearsimultaneous contract expiration dates. In 1986, UPIU engaged in coordinated bargaining at these and other mills. Though concessions were given on health care and work rules, the unions were able to maintain Sunday premium pay. While the company asserts that this outcome accorded with its bargaining strategy (Trefts interview), UPIU and others viewed it as a victory of unified bargaining (Johnston interview; Getman and Marshall 1993; Birecree 1991b).

The strategy changed somewhat in the next round of bargaining with these same mills. In the 1989 bargaining round, locals at the seven white paper mills formed a voting pool. Each local's ratification votes were sent to UPIU headquarters for counting. According to the pool rules, none of the participating locals would sign the agreement if a majority of the pool voted for rejection. However, if the pool voted for ratification, the international allowed individual locals which voted against it to either strike or work under implemented contracts.

In 1989, the company was determined to eliminate premium pay and unilaterally implemented those and other contract terms when the unions refused to go along. Unions at three locations voted to accept the implemented terms relatively early, with contracts going into effect in Fall 1989 or early in 1990. Strike authorization votes were taken and passed at the other four locations in June 1990 (The Paperworker, July 1990: 3). Ratification votes were held at these same four sites in late August. Two locations accepted contracts at that time (The Paperworker, September 1990: 3). The remaining two finally agreed to the proposals in November and December 1990 (The Paperworker, December 1990: 4; January 1991: 3). It is interesting

11. Interviews with international union officers, business representatives and local leadership of both the UPIU and AWPPW have uncovered this pattern throughout the industry. 
to note that aside from some difference in "crewing" language, there is a high degree of similarity among the contracts (UPIU Negotiation Reports). ${ }^{12}$

Early on, the company also filed unfair labour practice (ULP) charges against the union for failure to bargain in good faith. NLRB Region 3 issued a charge in 1990 which the union appealed to the national Board (Pulp and Paper, January 1990: 78; The Paperworker, September 1990). The charge was dropped in 1991 when the parties began efforts to rebuild their relationship through a national cooperative agreement.

\section{Case Analysis}

In this case, the union was the moving party behind the ultimately unsuccessful attempt to alter the bargaining structure. Its motivation was simply to gain (or regain) power. The decision to pool came in the context of ever worsening contract terms. Indeed, the 1988 amendment to the UPIU constitution on pooling specifically states that "Locals may choose to engage in coordinated bargaining to enhance their bargaining strength" (Constitution of the United Paperworkers International Union 1992: 44, emphasis added). Equally clear was management's opposition to this attempt. This opposition was manifested most explicitly in the filing of unfair labour practice charges against the union. Why was management opposed? In the words of one Champion manager, the pool was "purely about power", nothing more than a "threat to use force to achieve bargaining objectives" (Trefts interview).

On the surface, it would appear that work reorganization was also a factor. As described above, there were some differences in the crewing contract language. But at least one participant reports that relaxation of work rules had largely been achieved in 1986. Further, according to this same source, work reorganization had nothing to do with the bargaining strategy and indeed was "conducted independently of bargaining" (Trefts interview, see also Walton et al. 1994).

Beyond the obvious reasons for resisting any shift in bargaining power toward one's opponent, the environment was also putting pressures on Champion to reduce labour costs. Champion's takeover of St. Regis had saddled it with a considerable debt burden. Further, the product markets Champion operated in were largely commodity markets where there was growing competition on price. Other pressures or concerns were shared

12. Although all seven contracts contain straight time for weekend work, the starting points and therefore the size of the concession differed among the group. This is reflected in differences in lump sum bonuses which were intended to "buy out" premium pay. It might also be noted that although percent increases were quite similar, the base rates with which each unit began varied by more than a dollar and a half an hour. 
with other companies in the industry: small but growing international competition and a poor evaluation of the industry (and the company) by Wall Street (Trefts interview; Konzelmann Smith, Birecree and Wilkinson 1996: 24).

Finally, given the parties differing views as to the appropriate structure, this is a case where power was not only the cause of that difference but also a determinant of the outcome. That is, Champion exercised its legal right to implement contract terms. The local unions, unable to muster sufficient internal solidarity and facing an unfair labour practice charge on the pooling, capitulated one by one while the national was unable or unwilling to force them to do otherwise.

\section{International Paper}

While UPIU had acquiesced in the dismantling of the SKM in 1984, soon thereafter the union began trying to reestablish some centralization in bargaining with IP. In March 1987, IP initiated a lockout at its Mobile mill when the five local unions at that location refused to accept a series of concessions. Two months later, at a meeting with UPIU President Wayne Glenn, the Mobile locals agreed to form a voting pool with locals at three other IP sites: Jay, Maine; DePere, Wisconsin; and Lock Haven, Pennsylvania. Again, none of the participating locals would sign an agreement until all ratified an acceptable agreement. Strikes ensued at the other three locations and IP continued operations with supervisory personnel and permanent replacements.

Local leaders had hoped that as local unions from additional IP locations joined the pool, IP would find it increasingly difficult to continue operations. Instead, other locals, including those at Pine Bluff and Texarkana, Arkansas (Getman and Marshall 1993) and Moss Point, Mississippi (Bragg interview), decided to stay out of the pool and agreed to IP's proposals. Although UPIU President Glenn refused to sign off on these contracts, IP implemented the terms which the locals had accepted. In addition, IP filed an unfair labour practice charge against UPIU. Following a meeting at which it became clear that other locals would not join the pool or strike, the union ended the sixteen-month strike. The locals at the striking locations were later decertified. It might be added that while the company resisted union centralization efforts, it was consolidating previously disparate regional (North/South) labour relations policies (Birecree 1991b).

In June 1989, UPIU started another IP pool (Getman and Marshall 1993) of twenty-five UPIU locals at twenty-five IP mills in fourteen states (Daily Labor Report, February 10, 1992: A8). Ratification votes on IP final 
offers were taken at several of these locations and in December 1991 the pooled votes were counted; a majority had voted to reject (Getman and Marshall 1993). In one case, the Erie mill, the local voted to accept the contract and communicated this to the company. The International would not approve the contract, however, until the entire pool voted for acceptance (140 LRRM 2790).

In the meantime, IP filed an unfair labour practice charge against the union. In mid-1992, the NLRB sought and obtained an injunction against the pool (Kobell v. Paperworkers Union, 140 LRRM 2788). Later that year, the NLRB affirmed an Administrative Law Judge's finding that UPIU had committed an unfair labour practice with its voting pool (141 LRRM 1162). The Board reasoned that the pool violated the LMRA's requirement to bargain in good faith in that local unions had refused to sign contracts "on the basis of a nonmandatory subject of bargaining", that is, the terms and conditions of employment for another, separate bargaining unit.

By the time these rulings appeared, UPIU had already made a tactical change to avoid their consequences. In February 1992, it replaced the voting pool with a "coordinated bargaining pool". This involved an agreement among local unions that the national President could refuse to approve any local contract that did "not contain language recognizing the right of Union members to honour the pickets of other unionized workers" (140 LRRM 2791; The Paperworker, March 1992). ${ }^{13}$

\section{Case Analysis}

The dynamics at work in this case closely parallel those of the Champion pooling case. The union, motivated by losses at the bargaining table and, in this case, decertified locals, sought to centralize. IP, resisting the "power play", filed charges and ultimately prevailed when the NLRB ruled in favour of the company. IP's motives were both tactical and economic. Indeed, IP's Director for labour relations indicates that the original Mobile lock-out was a response to the success of UPIU's coordinated strategy at Champion in 1986 (Birecree 1991b). The economic environment, in the company's view, demanded reduced labour costs and these would not be achievable if the union pursued its centralizing strategy.

13. Shortly thereafter, members of the Coordinated Bargaining Pool and other members of UPIU's IP Council took another step to resist NLRB limitations on their strategy. They signed a "Resolution of Strength" pledging to: "make any necessary future modifications to the Pool agreement, such as a cut-off date or the establishment of minimum acceptance standards, to assure the future legality of the Pool... [ and] to refuse to promote, endorse, or sign any contract with International Paper that does not meet the minimum standards of common expiration date during the last quarter of 1994 and no concessions" (A Resolution of Strength 1992). However, this resolution was never implemented (Bragg interview). 
Though work reorganization was on the table in some of the local negotiations (notably in Jay), locals did not offer it as an "excuse" for their resistance to the pool. Stronger explanations for the union's failure to fully implement the pool lie in locals' legitimate fears regarding the likelihood of replacement. Internal union politics also played a role. The tactics used by the locals participating in the 1987 strike focused on rank and file activism. Interviews with national leaders suggest that the national's failure to fully support the strike and push the pool resulted from fears that successful local strike leaders might mount an effective challenge to the national leadership (Getman 1996).

\section{EVENTS IN THE 1990S}

Even after the major concessionary period of the mid-1980s, management continued to dismantle centralized bargaining structures. In 1991, Georgia-Pacific dissolved the multi-mill structure comprised of the former Great Northern Nekoosa mills (Wall, personnel correspondence). In 1993, Boise Cascade chose to bargain with its five west coast mills individually thereby ending a year bargaining relationship established in 1971 (Thompson interview). The remaining multi-mill contracts are concentrated largely in converting operations where other factors, including the low percentage of workers organized and the relative ease with which companies can move operations, keep union bargaining power in check.

At the same time, the early 1990s saw labour and management in some companies in the paper industry put the bitter wars of the 1980 s behind them. For example, Scott and James River, generally considered two of the less aggressive bargainers in the mid-1980s, negotiated and implemented national joint agreements to "cooperate" in 1989. Champion, with considerable repair work to do in its relationship with the unions and their employees, reached an agreement with UPIU in 1991. These agreements provided for mutual respect, company neutrality in organizing drives ${ }^{14}$ and leadership "support" for local efforts at cooperation and employee participation. They stimulated centralized discussions, if not negotiations, on some issues.

For example, in 1993 Scott moved away from decentralized bargaining and allowed a "first ever joint bargaining agreement" between local unions in two Wisconsin mills (The Paperworker, May 1993). Further, when Scott announced a major restructuring effort in 1994, including a workforce reduction of 10,400, the joint advisory committee (JAC) negotiated incentive severance pay and incentive retirement pay plans for all

14. Neutrality is not part of the Champion agreement. 
UPIU employees (The Paperworker, September 1994: 14). As a result of this agreement, virtually no union workers were involuntarily laid off (Scott Council meeting June 3, 1995). These events provide some support for our argument that a strategic-level "efficiency" strategy might aid centralization of bargaining.

\section{SUMMARY AND CONCLUSIONS}

This study has strengthened our understanding of the determinants of bargaining structure, and particularly, the recent trend toward decentralization, through two approaches. First, it has integrated three waves of theoretical and empirical work on the topic: the observations of post-war scholars arising primarily from industry case studies; Hendricks and Kahn's bargaining framework and related econometric analyses; and the recent case study research by Katz and Voos focusing on decentralization. Secondly, it has applied this integrated framework to a series of significant case studies at the bargaining unit level within one industry.

Table 2 summarizes each of the hypotheses initially presented and their usefulness in explaining the four case studies. What emerges from this synopsis is that management's desire to increase or preserve bargaining power was a driving motivation for its behaviour in all four cases. And because management's power in general was on the rise in the 1980s, employers possessed the tools for exerting influence over bargaining structure. Thus, when the parties' preferences clashed, management used various weapons, including the law, to prevail.

Companies in other industries which pushed to decentralize bargaining structures often did so in direct reaction to increased competition due to globalization, deunionization or other changes in their product or labour markets. These are factors traditionally considered important determinants of bargaining structure. When paper managers described the increased competition in their industry, they spoke about the potential rather than actual impact of these traditional factors (Eaton and Kriesky 1994). The changing market conditions actually experienced were those of rising profit expectations in financial markets. The capital-intensive character of the paper industry requires investment in plant and equipment to improve profits by improving productivity. Thus, given the time and expenditure such changes require, reductions in the variable costs represented by labour emerged as the short-run method to bolster financial performance (see Kaufman 1996 for a similar argument). At the same time, work rule changes that enabled the maximal use of capital also boosted financial performance. 
TABLE 2

Evaluation of Hypotheses against Evidence in Each Case

\begin{tabular}{|c|c|c|c|c|}
\hline Hypotheses & Northwest & $S K M$ & $\begin{array}{l}\text { Champion } \\
\text { Pool }\end{array}$ & IP POOl \\
\hline \multicolumn{5}{|l|}{ I. Management Resistance to Centralization } \\
\hline \multicolumn{5}{|l|}{$\begin{array}{l}\text { Provoked by: } \\
\text { A. Economic/Market Factors }\end{array}$} \\
\hline \multicolumn{5}{|l|}{ A. Economic/Market Factors } \\
\hline $\begin{array}{l}\text { 1. In the case of multi-employer } \\
\text { structures, the broadening of markets } \\
\text { or integration of regional operations }\end{array}$ & Weak & N/A & N/A & N/A \\
\hline 2. increased product diversity & No & No & No & No \\
\hline \multicolumn{5}{|l|}{ 3. increased competition: } \\
\hline a. decreased concentration & No & No & No & No \\
\hline b. deunionization & Weak & Weak & Weak & Weak \\
\hline c. foreign competition & Weak & Weak & Weak & Weak \\
\hline \multicolumn{5}{|l|}{ B. Tactical Factors } \\
\hline $\begin{array}{l}\text { 4. belief that decentralization would } \\
\text { increase or maintain mgt. power }\end{array}$ & Yes & Yes & Yes & Yes \\
\hline \multicolumn{5}{|l|}{ C. Organizational/Political Factors } \\
\hline $\begin{array}{l}\text { 5. decentralization in corporate } \\
\text { structures }\end{array}$ & N/A & No & No & No \\
\hline 6. Mgt. pursuit of work reorganization & Yes & Yes & No & No \\
\hline \multirow{2}{*}{\multicolumn{5}{|c|}{$\begin{array}{l}\text { II. Union Preferences: } \\
\text { A. Economic/Markets Factors }\end{array}$}} \\
\hline A. Economic/Markets Factors & & & & \\
\hline $\begin{array}{l}\text { 7. Unions will try to take wages out of } \\
\text { competition through formal OR } \\
\text { informal centralization OR will pursue } \\
\text { an efficiency strategy }\end{array}$ & Yes & Yes & Yes & Yes \\
\hline $\begin{array}{l}\text { 7a. Unions will pursue formal } \\
\text { centralization when pattern bargaining } \\
\text { fails }\end{array}$ & Yes & N/A & Yes & Yes \\
\hline $\begin{array}{l}\text { 8. formal centralization pursued by nat'l } \\
\text { when locals reaching bad'agreements }\end{array}$ & No, but* & N/A & No & $\begin{array}{l}\text { No, } \\
\text { but* }\end{array}$ \\
\hline \multicolumn{5}{|l|}{ B. Tactical Factors } \\
\hline $\begin{array}{l}\text { 9. Union agreed to decentralization } \\
\text { believing it wouldn't decrease power }\end{array}$ & Yes** & Yes** $^{*}$ & N/A & N/A \\
\hline $\begin{array}{l}\text { 10. Union pursued centralization believing } \\
\text { it would increase power }\end{array}$ & Yes & N/A & Yes & Yes \\
\hline \multicolumn{5}{|l|}{ C. Organizational/Political Factors } \\
\hline $\begin{array}{l}\text { 11. difficulties in creating/maintaining } \\
\text { centralized structures a function of } \\
\text { local/nationall power balance }\end{array}$ & Yes & Yes & Yes & Yes \\
\hline $\begin{array}{l}\text { 12. rising importance of work } \\
\text { reorganization provoked support for } \\
\text { decentralization }\end{array}$ & No & No & No & No \\
\hline \multicolumn{5}{|l|}{ III. When Preference Clash: } \\
\hline 13. power will determine outcome & N/A & $\begin{array}{l}\text { N/A, } \\
\text { but }\end{array}$ & Yes & Yes \\
\hline
\end{tabular}

* In both cases, locals were reaching "bad" agreements, but the push to centralize came from other locals, not the national union.

** In both cases, the union proved to be wrong.

*** While there was no open struggle over the change in structure, one could argue that UPIU was coerced into agreeing to the change. 
Decentralization of corporate structure did not play a role in the paper industry. While paper companies did push some authority lower in the organization, formal bargaining structures had already shifted in some cases. Further, managers interviewed make clear that whatever the formal structure of bargaining, centralized corporate coordination and control is still essential. However, management in the Northwest and SKM cases specifically noted that work reorganization was influential in their decentralization decisions. Thus, the paper industry appears to confirm Katz's view that work reorganization has in large part motivated decentralization. However, in the paper industry it becomes difficult to disentangle work organization and bargaining power. Our evidence indicates that management was better able to implement its preferred work rule changes when negotiating in each mill individually. Decentralization made it difficult for the paper unions to resist or shape work reorganization.

Management's use of its power to secure a favourable position and to amass more power, forced the unions into a defensive stand. The UPIU and AWPPW sought (mostly unsuccessfully) to find a way to retain or regain their ability to keep wages out of competition. As the evaluation of hypotheses suggests, however, the unions' lack of success resulted largely from tactical and organizational/political considerations as well as from the economic context.

In all four cases, the unions' political problems in creating or holding together centralized structures weakened them vis-à-vis management. The weak internal centralization of both the AWPPW and the UPIU meant that local unions actually took the initiative to recentralize when they realized that patterns were failing. The tradition of strong local and regional autonomy that had served both unions well in an earlier time, left them considerably weaker as the bargaining posture of management shifted. In the AWPPW case, the frustrated and strong-willed locals made a tactical error in believing that decentralization would work in their favour. Similarly UPIU's decision to allow locals to choose whether or not to participate in the IP pool fatally damaged the effort. What remains unanswered is the question of whether a unified strategy would have been sufficient to counteract management's power in any of these cases.

Although case study research, or indeed any other form of investigation, cannot provide an answer to this final question, this examination uncovers representative trends in the paper industry. Though some of the details of the dissolution of other paper industry bargaining structures and of other pooling cases may vary, the factors at work in the four cases reviewed here appear applicable to these events. While some recent observers have downplayed the importance of power in the trend towards 
decentralization, it was clearly a factor in the paper industry. We would not argue that the experience in paper is representative of all other manufacturing (or service) industries in the United States or other nations. But such case study research provides as a starting point a more complete analytical framework than previously available, for identifying fully the complex factors motivating decentralization in these other cases.

\section{REFERENCES}

BECK, John P. 1988. "The Pattern Bites Back: The Dominance of the South in Paper Industry Bargaining and Worklife." Society for the Study of Social Problems Meeting, Atlanta, Georgia, August 21-23.

BIRECREE, Adrienne. 1991a. "Capital Restructuring and Labour Relations: The International Paper Company Strike." International Contributions to Labour Studies, Vol. 1, 1-28.

BIRECREE, Adrienne. 1991b. Unpublished notes from interviews with James Gilliland, Director of Employee Relations, International Paper.

BOURQUE, Reynald and Claude RIOUX. 1997. "Industrial Restructuring and Union Response: The Experience of the Fédération des travailleurs du papier et de la forêt in Quebec." Labor Studies Journal, Vol. 22, No. 2, 321.

BROTSLAW, Irving. 1964. "Trade Unionism in the Pulp and Paper Industry." Unpublished Ph.D. Dissertation, University of Wisconsin.

COBBLE, Dorothy Sue and Michael MERRILL. 1994. "Collective Bargaining in the Hospitality Industry in the 1980s." Contemporary Collective Bargaining in the Private Sector. Paula B. Voos, ed. Madison, Wisc.: Industrial Relations Research Association, 447-490.

Daily Labor Report. Washington, DC: Bureau of National Affairs.

DEATON, D. R. and P. B. BEAumont. 1980. "The Determinants of Bargaining Structure: Some Large Scale Survey Evidence for Britain." British Journal of Industrial Relations, Vol. 18, No. 2, 202-216.

EATON, Adrienne, and Jill KRIESKY. 1994. "Collective Bargaining in the Paper Industry: Developments Since 1979. Contemporary Collective Bargaining in the Private Sector. Paula B. Voos, ed. Madison, Wisc.: Industrial Relations Research Association, 25-62.

FIORITO, Jack, Cynthia Gramm and Wallace HENDRICKS. 1991. "Union Structural Choices." The State of the Unions. G. Strauss, D. Gallagher, and J. Fiorito, eds. Madison, Wisc.: Industrial Relations Research Association.

GETMAN, Julius. 1996. "Learning from Failure in Strikes and Organizing." Unpublished paper, University of Texas School of Law. 
Getman, Julius and Ray Marshall. 1993. "Industrial Relations in Transition: The Paper Industry Example." Yale Law Review, Vol. 102, No. 8, 1804-1895.

GRAHAM, Harry Edward. 1970. The Paper Rebellion: Development and Upheaval in Pulp and Paper Unionism. Iowa City: University of Iowa Press.

GREENBERG, David. 1966. "The Structure of Collective Bargaining and Some of Its Determinants." Proceedings of the Nineteenth Annual Winter Meeting of the Industrial Relations Research Association. Madison, Wisc.: IRRA, 343-353.

GUTHRIE, John A. 1972. An Economic Analysis of the Pulp and Paper Industry. Pullman, Wash.: Washington State University Press.

HENDRICKS, Wallace and Lawrence KAHN. 1982. "The Determinants of Bargaining Structure in U.S. Manufacturing Industries." Industrial and Labor Relations Review, Vol. 35, No. 2, 181-195.

INTERNATIONAL PAPER COMPANY. GEORGETOWN MILL AND UNITED PAPER WORKERS INTERNATIONAL UNION, AND INTERNATIONAL BROTHERHOOD OF ELECTRICAL WORKERS. 1992. Labor Agreement.

KATZ, Harry C. 1993. "The Decentralization of Collective Bargaining: A Literature Review and Comparative Analysis." Industrial and Labor Relations Review, Vol. 47, No. 1, 3-22.

KAUFMAN, Bruce E. 1996. "The Emergence and Growth of a Nonunion Sector in the Southern Paper Industry." Essays in Recent Southern Labor History. R. Zieger, ed. Knoxville: University of Tennessee Press.

KERR, Clark, and Roger RANDALL. 1948. Collective Bargaining in the Pacific Coast Pulp and Paper Industry. Philadelphia: University of Pennsylvania Press.

KOCHAN, Thomas A. 1980. Collective Bargaining and Industrial Relations. Illinois: Richard D. Irwin.

KOCHAN, Thomas A. and Michael PIORE. 1983. "Will the New Industrial Relations Last? Implications for the American Labor Movement." The Annals of the American Academy of Political Science, No. 473, 177-198.

KOCHAN, Thomas A., Harry C. KATZ and Robert B. MCKERSIE. 1986. The Transformation of American Industrial Relations. N.Y.: Basic Books.

KOCHAN, Thomas A. and Harry C. KATZ. 1992. An Introduction to Collective Bargaining and Industrial Relations. N.Y.: McGraw-Hill.

KONZELMANN SMITH, Suzanne, Adrienne BIRECREE and Frank WILKINSON. 1996. "The Costs and Benefits of Adversarial and Cooperative Approaches to Solving Competitive Problems: A Theoretical Analysis." Unpublished paper, Indiana University South Bend.

KRIESKY, Jill and Edwin BROWN. 1993. "The Union Role in LaborManagement Cooperation: A Case Study at the Boise Cascade Company's Jackson Mill." Labor Studies Journal, Vol. 18, No. 3, 17-32. 
Labor Relations Reference Manual (LRRM). Washington, D.C.: Bureau of National Affairs.

LEVINSON, Harold M. 1966. Determining Forces in Collective Wage Bargaining. New York: John Wiley and Sons.

MACDONALD, Robert M. 1956. "Pulp and Paper." The Evolution of Wage Structures. L.G. Reynolds and C.H. Taft, eds. New Haven: Yale University Press.

The Paperworker. Nashville, Tenn.: United Paperworkers International Union.

Pulp and Paper. New York: Miller Freeman Periodicals.

The Rebel. Portland, Oreg.: Association of Western Pulp and Paper Workers.

"A Report to Our Employees". 1983. International Paper Company. Multiple Mill Group Industrial Relations Department.

SCHURMAN, Susan and Adrienne E. EATON. 1996. "Labor and Workplace Democracy: Past, Present and Future. Introduction to the Special Issue." Labor Studies Journal, Vol. 21, No. 2, 3-27.

U.S. DePARMEnT OF LABOR (U.S. DoL). 1967. Wage Chronology: International Paper Company, Southern Kraft Division, 1937-76. Bulletin No. 1534, Bureau of Labor Statistics. Washington, D.C.: U.S. Government Printing Office.

Voos, Paula B. 1994. "An Economic Perspective on Contemporary Trends in Collective Bargaining." Contemporary Collective Bargaining in the Private Sector. Paula B. Voos, ed. Madison, Wisc.: Industrial Relations Research Association, 1-24.

WALTON, Richard E., Joel E. CUTCHER-GERSHENFELD and Robert B. MCKERSIE. 1994. Strategic Negotiations: A Theory of Change in LaborManagement Relations. Boston: Harvard Business School Press.

WEBER, Arnold R., ed. 1961. The Structure of Collective Bargaining. New York: The Free Press of Glencoe.

WEBER, Arnold R. 1967. "Stability and Change in the Structure of Collective Bargaining." Challenges to Collective Bargaining. Lloyd Ulman, ed. Englewood Cliffs: Prentice-Hall.

ZIEGER, Robert H. 1984. Rebuilding the Pulp and Paper Workers' Union, 1933-1941. Knoxville: University of Tennessee Press.

Interviews and Correspondence

BRADSHAW, Joe. UPIU Regional Vice President, Region 7. December 2, 1992.

BRAGG, Frank. UPIU Special Projects. June 22, 1993 and July, 1996.

BREHM, Gordon. Special Assistant to the President, United Paperworkers International Union. November 9, 1992 and Feburary 19, 1993. 
GILLILAND, James. Director of Employee Relations, International Paper, Retired. February 29, 1996.

GWARTNEY, Michael. Vice President for Human Resources, Boise Cascade. August 5, 1996.

JOHNSTON, Gerald. UPIU Regional Vice President, Region 8. December 23, 1992.

KLINZING, Richard. Vice President for Human Resources, American Forest and Paper Association. December 8, 1992 and January 5, 1993.

LANGHAM, Donald. UPIU Regional Vice President, Region 5. March 15, 1995.

LARSON, Keith. Human Resource Manager, James River-Wauna. July 12, 1996.

LAWTON, Robert. Managing Director, Pacific Coast Association of Pulp and Paper Manufacturers. March 21, 1995 and February 28, 1996.

REYNOLDS, David. Former Vice President for Human Resources, Georgia Pacific. August 7, 1996.

ROBERTS, Leonard. President, Association of Western Pulp and Paper Workers, January 16, 1996.

THOMPSON, James A. General Vice President, Association of Western Pulp and Paper Workers. December 13, 1993.

TREFTS, Byron. Vice President for Corporate Labor Relations, Champion International Corporation. January 19, 1993 and March 1, 1996.

WALL, R. J. Manager. Personal correspondence to Adrienne Eaton. November 19, 1993.

WEITMAn, Ted. Assistant Human Resource Manager, James River-Halsey. July 10, 1996.

\section{RÉSUMÉ}

Décentralisation des structures de négociation : quatre cas tirés de l'industrie du papier américaine

Ces dernières années, partout dans le monde, il y a eu une décentralisation croissante des structures de négociation collective. Dans la présente étude, nous nous servons de deux méthodes pour analyser, plus profondément que ne l'ont fait les études antérieures, les facteurs déterminants des structures de négociation. D'abord, nous élaborons un cadre d'analyse de ces structures en intégrant les travaux théoriques et empiriques précédents sur ce sujet. Ensuite, nous appliquons ce cadre à l'étude de quatre unités de négociation dans l'industrie du papier aux États-Unis. L'étude révèle l'importance relative des facteurs économiques, stratégi- 
ques et organisationnels dans la décentralisation continue des structures de négociation au cours des années 1980.

La décentralisation de ces structures est largement connue, mais ses causes et les processus qui y ont conduit le sont beaucoup moins. La documentation examinée rassemble les études importantes effectuées par Katz (1993), Voos (1994), Weger (19967), Hendricks et Kahn (1982) et Deaton et Baumont (1980), ainsi que plusieurs autres travaux qui se limitent à mentionner les facteurs déterminants des structures de négociation. À la suite de Hendricks et Kahn, le cadre analytique élaboré dans la présente étude porte sur ce qui détermine les préférences du patronat et des syndicats pour certaines structures de négociation et la manière dont ces préférences en interaction édifient les structures réelles. Ces déterminants sont classés en trois grandes catégories : les facteurs économiques ou de marché, les facteurs stratégiques et les facteurs organisationnels. Chacune de ces catégories a été considérée comme une explication possible de la décentralisation récente.

Nous comparons une série d'hypothèses sur les causes et l'orientation des choix de l'employeur et du syndicat relativement aux structures de négociation à partir de quatre études de cas tirés de l'industrie du papier américaine. Ces études reposent sur des sources d'information primaires et secondaires et ont été choisies en raison de leur incidence sur la négociation dans l'ensemble de l'industrie. Deux cas ont trait au démantèlement des structures modèles les plus importantes dans l'industrie, lesquelles étaient en place avant la détérioration des conditions de travail prévues aux conventions. Un des deux concerne la disparition définitive de la négociation avec plusieurs employeurs dans le nord-ouest; l'autre examine la mort de la structure régionale de négociation multi-établissements d'International Paper Company (IP), connue sous le nom de Southern Kraft Multiple (SKM). Les deux autres cas décrivent les tentatives d'établir des regroupements de votants à IP et à Champion International. Ces regroupements ont constitué le mécanisme principal choisi par l'organisation syndicale de base de l'industrie pour revenir à un certain degré de négociation centralisée.

L'analyse du premier cas montre que le mouvement vers la décentralisation est venu aussi bien du syndicat que de l'employeur. En effet, les sections locales ont délaissé finalement la structure centralisée parce qu'elle venait en conflit entre le besoin stratégique d'unité et celui de disposer de résultats adaptés à chaque section locale. Les employeurs ont fait de même. L'engagement de coopération entre les entreprises qui avait mené à des structures de négociation fructueuses a été délaissé. Dans certaines entreprises, la concurrence de l'industrie du papier en expansion dans le sud a conduit les employeurs à concentrer leurs efforts sur l'orga- 
nisation du travail et la flexibilité des emplois, bien que les syndicats locaux aient passablement réussi à s'opposer aux changements contractuels.

Dans le cas de la SKM, l'organisation du travail (vue par Katz comme le motif principal de la décentralisation en général) et le pouvoir de négociation sont difficilement séparables. IP a affirmé publiquement que la décentralisation était motivée par la réorganisation du travail, mais ses motifs étaient avant tout économiques et stratégiques. Certes, IP a proposé aux sections locales des changements de libellé uniformes pour toute la société, mais a soutenu en même temps la nécessité de négocier séparément avec chaque syndicat local. Une grave crise financière, attribuable à une profonde récession et à un ensemble de décisions relatives aux investissements prises au mauvais moment, ont poussé IP à exercer son pouvoir de négociation pour forcer l'assentiment des syndicats à décentraliser la négociation aussi bien qu'à réorganiser le travail. En bout de ligne, la négociation décentralisée a rendu plus difficile aux syndicats de l'industrie du papier leur opposition à la réorganisation du travail.

Dans le premier des cas de recentralisation, le syndicat, au moment où il était en négociation avec Champion, a tenté le regroupement des votants pour chercher à accroître son pouvoir vis-à-vis de l'employeur. Ce dernier s'y est opposé pour cette raison même. De plus, Champion était forcée de réduire le coût de sa main-d'œuvre en raison de facteurs circonstanciels, notamment : a) sa dette encourue par sa récente prise de contrôle d'une autre entreprise de papier; b) les prix concurrentiels du marché des produits de base où elle exerçait son activité; c) la concurrence internationale faible mais croissante; d) l'évaluation peu élevée de l'industrie faite par les analystes financiers. Champion a exercé son pouvoir en faisant valoir ses droits légaux de fixer les conditions contractuelles et de déposer des accusations de pratiques de travail déloyales relativement à la stratégie de regroupement des votants. Ainsi, le pouvoir était donc non seulement la cause de la différence de point de vue des parties quant à la structure de négociation appropriée, mais aussi un facteur déterminant de l'issue de la situation.

La dynamique du second cas de regroupement, qui a de nouveau concerné IP, suit de près celle exposée précédemment. Le syndicat, motivé par des pertes à la table de négociation et, dans ce cas, par la désaccréditation de syndicats locaux, a cherché à centraliser la négociation. IP s'y est opposée en déposant des accusations de pratiques déloyales contre le syndicat, pour lesquelles le tribunal lui a finalement donné raison. De nouveau, les motifs d'IP étaient à la fois économiques et stratégiques. En fait, IP a admis que la stratégie de la société constituait en grande partie une réaction à la stratégie syndicale de regroupement des 
votants qui avait réussi chez Champion. Là encore, le contexte économique exigeait la réduction des coûts de la main-d'œuvre, qui ne pouvait se faire si le syndicat poursuivait avec succès sa stratégie de centralisation. Dans ce casci, toutes les sections locales n'ont pas accepté le plan de regroupement. La réorganisation du travail était un élément en jeu à la table de négociation de certains de ces syndicats locaux. Ces derniers ont donc invoqué des craintes légitimes à l'égard de la possibilité de congédiements et affirmé que les politiques syndicales internes étaient des facteurs importants dans leur décision de ne pas participer à une tentative de centralisation.

En conclusion, la présente étude montre que le désir de l'employeur de préserver ou d'accroître son pouvoir de négociation a motivé son comportement dans chacun des quatre cas. Et puisque le patronat a joui d'un pouvoir à la hausse dans les années 1980, il possédait l'outil nécessaire pour influencer les structures de négociation. Dans d'autres industries, les gestionnaires ont pu être directement motivés par la concurrence accrue dans le marché des produits (en particulier, les sources d'approvisionnement internationales) ou les changements dans le marché du travail (entre autres, la désyndicalisation). Cependant, pour les gestionnaires des entreprises du papier, ces facteurs ont été plus hypothétiques que réels. Pour ces entreprises en effet, c'est la hausse des attentes des marchés financiers qui a véritablement mené au changement. Pour améliorer la productivité et, partant, les profits, l'industrie du papier, qui est à forte intensité de capital, exige des investissements à long terme dans les usines et l'équipement. La réduction des coûts variables représentés par la main-d'œuvre et la modification des règles de travail qui rend possible l'utilisation maximale du capital sont apparus comme étant les méthodes à court terme capables de soutenir le rendement financier. En négociant avec chaque usine séparément, l'employeur avait plus de chances d'effectuer les changements souhaités aux règles de travail, malgré les objections syndicales. En outre, dans les quatre cas, les problèmes politiques des syndicats lorsqu'ils mettaient en place ou maintenaient des structures de négociation centralisées les ont affaiblis vis-à-vis de l'employeur. La grande autonomie locale et régionale avait bien servi les syndicats à une époque antérieure, mais a miné leurs tentatives de recentralisation au moment où ils se sont rendu compte que le modèle de négociation décentralisée menait à l'échec. Il est clair que l'expérience faite dans l'industrie du papier n'est pas représentative de toutes les industries manufacturières et de services, que ce soit aux États-Unis ou ailleurs. Toutefois, la présente recherche sur les quatre cas décrits et le cadre d'analyse élaboré ici fournissent un point de départ à la définition com- 
plète des facteurs complexes qui motivent la décentralisation dans les autres cas.

\section{RESÚMEN}

La descentralización de la estructura de negociación : Cuatro casos de la industria del papel en los Estados Unidos

En años recientes, varios países en el mundo han experimentado con la descentralización de las estructuras de negociación. Este estudio contiene dos métodos que permiten una estudio mas profundo que los estudios anteriores de los factores que influencian estas decisiones. Primero, creamos un marco de análisis de la estructura de negociación al integrar el trabajo teórico y practico de varios puntos. Después este marco es aplicado a cuatro casos particulares en la industria del papel en los Estados Unidos. Al examinar la disolución de dos centrales de ne3gociacion y los intentos de los sindicatos por restablecer la unidad central de negociación en dos otras instancias, el estudio nos permite ver la importancia relativa de los factores económicos, tácticos y de organización en la continua descentralización de las estructuras de negociación en la industria del papel en los Estados Unidos en los años ochenta. 